\title{
Analysis of musculoskeletal disorders symptoms in professors of the University of Pernambuco - Petrolina Campus*
}

\author{
Análise da sintomatologia de distúrbios osteomusculares em docentes da Universidade de \\ Pernambuco - Campus Petrolina
}

José Pereira de Lima Júnior ${ }^{1}$, Tarcísio Fulgêncio Alves da Silva ${ }^{1}$

${ }^{*}$ Received from University of Pernambuco, Petrolina, PE, Brazil.

DOI 10.5935/1806-0013.20140060

\section{ABSTRACT}

BACKGROUND AND OBJECTIVES: College professors are exposed to numerous pressure sources which affect their quality of life and professional activities. Notwithstanding, studies discussing musculoskeletal disorders in this population are still scarce in the literature. This study aimed at evaluating symptoms of work-related musculoskeletal disorders among professors of the University of Pernambuco - Petrolina Campus.

METHODS: Sample was made up of 49 professors and to obtain musculoskeletal symptoms prevalence and typology, the Nordic Musculoskeletal Symptoms Questionnaire was used, as well as the visual analog scale to evaluate pain intensity.

RESULTS: The prevalence of musculoskeletal symptoms was $85.7 \%$, being that $64.3 \%$ have reported that symptoms are related to and worsen with teaching activities, being cases suggestive of work-related musculoskeletal disorders. Most affected anatomic region was lumbar spine $(54.8 \%)$, followed by cervical spine $(45.2 \%)$, shoulders $(23.8 \%)$ and wrists/hands (23.8\%). Most prevalent regions with severe pain were upper limbs (36.8\%), lower limbs (32.0\%) and spine (21.9\%).

CONCLUSION: The studied sample had a high prevalence of musculoskeletal symptoms and acknowledged that symptoms are related to and worsen with teaching activities, being suggestive of work-related musculoskeletal disorders.

Keywords: Musculoskeletal pain, Professional diseases, Worker's health.

1. University of Pernambuco - Petrolina Campus, Department of Physiotherapy, Petrolina, PE, Brazil.

Submitted in September 12, 2014.

Accepted for publication in November 04, 2014.

Conflict of interests: none - Sponsoring sources: none.

Correspondence to:

Tarcísio Fulgêncio Alves da Silva

BR 203, Km 2, s/n, Vila Eduardo

56328-903 Petrolina, PE, Brasil.

E-mail: tarcisio.silva@upe.br

(C) Sociedade Brasileira para o Estudo da Dor

\section{RESUMO}

JUSTIFICATIVA E OBJETIVOS: Os docentes de ensino superior estão expostos a inúmeras fontes de pressão, afetando assim sua qualidade de vida e rendimento nas atividades profissionais. Apesar disso, estudos que discutam os distúrbios de caráter osteomuscular nesse público ainda são escassos na literatura. O objetivo deste estudo foi avaliar a sintomatologia de distúrbios osteomusculares relacionados ao trabalho em docentes da Universidade de Pernambuco Campus Petrolina.

MÉTODOS: A amostra foi composta por 49 docentes e para se obter a prevalência e tipologia dos sintomas osteomusculares, utilizou-se o Questionário Nórdico de Sintomas Osteomusculares, bem como a escala analógica visual para avaliar a intensidade de dor.

RESULTADOS: A prevalência de sintomas osteomusculares foi de $85,7 \%$, sendo que $64,3 \%$ relatam que os sintomas estão relacionados e pioram com a atividade de lecionar, sendo casos sugestivos de distúrbios osteomusculares relacionados ao trabalho. A região anatômica mais acometida foi a coluna lombar $(54,8 \%)$, seguida pela coluna cervical $(45,2 \%)$, ombros $(23,8 \%)$ e punhos/máos $(23,8 \%)$. As prevalências dos sintomas álgicos com intensidade grave foram nos membros superiores $(36,8 \%)$, nos membros inferiores $(32,0 \%)$ e na coluna vertebral $(21,9 \%)$.

CONCLUSÁO: $\mathrm{Na}$ amostra de docentes estudados, houve uma alta prevalência de sintomas osteomusculares, assim como a percepção de que a sintomatologia está relacionada e piora com a atividade de lecionar, sendo sugestivos de distúrbios osteomusculares relacionados ao trabalho.

Descritores: Doenças profissionais, Dor musculoesquelética, Saúde do trabalhador.

\section{INTRODUCTION}

The incidence of Work-Related Musculoskeletal Disorders (WRMD) is increasing in recent years, due to organizational changes and work relations requirements, often leading to medical leaves and workers' functional incapacity ${ }^{1}$. Such disorders are recognized as major causes of morbidity and incapacity ${ }^{2,3}$, being considered a public health problem ${ }^{4}$.

According to Ministry of Social Security technical standards, 
WRMD symptoms in general involve pain, paresthesia, sensation of weight and fatigue, in addition to encompassing musculoskeletal system diseases acquired by workers submitted to certain working conditions. The presence of such symptoms is a critical factor for individuals' negative perception of their health ${ }^{5}$. So, measuring WRMD reports is needed to collect data to quantify prevalence and to evaluate different affected populations.

Among tools to evaluate such symptoms, the Nordic Musculoskeletal Symptoms Questionnaire (NMSQ) is a tool developed to standardize musculoskeletal pain and discomfort, thus helping comparison of results of different studies and populations ${ }^{6}$.

Among these populations, college professors, for having administrative activities, conciliating teaching, research and extension, are exposed to numerous pressure sources, beyond those arising from changes in the labor system, such as high workload, short pauses for rest, intensive working pace and requirements for beyond those arising from changes in the labor system high levels of attention and concentration. When such situations are associated to a high level of stress, quality of life of this category is considerable impaired ${ }^{7,8}$, inducing several health disorders, such as musculoskeletal problems which are prevalent among professors?

So, college professors deserve attention as to potential health risks and problems related to their labor activity. So, studies addressing this population are important to justify physiotherapeutic actions on them, with preventive measures and actions, by means of evaluations and intervention projects, which shall act to fight musculoskeletal pain and discomfort, which is a necessary situation since it is unlikely to professors to work with satisfaction and quality feeling presenting this framework.

In addition, to present a new SRMD intervention model promoting changes in working conditions, and no longer implement palliative measures implying medical leaves of such professionals and, as a consequence, expenditures with health treatments and social security issues, making public resources to be geared to such objectives instead of providing real investments to improve working and health conditions ${ }^{10}$.

It is worth stressing that there are few scientific studies related to musculoskeletal risk factors among professors ${ }^{11}$, and this deficit is even more severe with regard to college professors since studies focus on professionals of other educational levels ${ }^{12}$.

In addition, the study is justified for analyzing WRMD symptoms in college professors of the University of Pernambuco - Petrolina Campus (UPE - Petrolina), and for focusing on possible triggering factors and repercussions in their professional and personal activities, allowing that interventions may be developed to improve their quality of life.

\section{METHODS}

This is a descriptive and crossover study developed between February and June 2014 in UPE-Petrolina, with professors of the institution. Inclusion criteria were professors effective- ly working at the University, according to the type of link: professors borrowed by other entities, with established term contract, and effective professors who accepted participating in the study. Exclusion criteria were professors on leave and those denying participating.

During data collection, 118 professors met inclusion criteria being the project presented to all professors through meetings. From these, 55 have answered and returned data collection tool being that only adequately answered questionnaires were analyzed to obtain results and so, 49 made up the studied sample.

Data were obtained after consent through a self-applicable questionnaire made up of questions of socio-demographic, occupational and life habits aspects, by NMSQ for musculoskeletal symptoms validated for the Brazilian population ${ }^{6}$, which is a tool with multiple choices regarding symptoms in different anatomic regions, as shown in figure 1.

The questionnaire has also evaluated volunteers' perception of pain intensity through the visual analog scale (VAS) ${ }^{13}$, scored from zero to 10 , where zero is no pain and 10 the worst imaginable pain, being classified as mild (1,2 and 3$)$, moderate (4, 5 and 6$)$ and severe $(7,8,9$ and 10), allowing accurate pain scoring, being also quick and easy to apply.

The level of physical activity (LPA) was obtained with the validated short version of the International Physical Activity Questionnaire (IPAQ) ${ }^{14}$, which has classified volunteers in active, irregularly active and sedentary.

\section{Statistical analysis}

Data were analyzed by the statistical software SPSS (Statistical Package for the Social Science) version 20.0. Initially, a

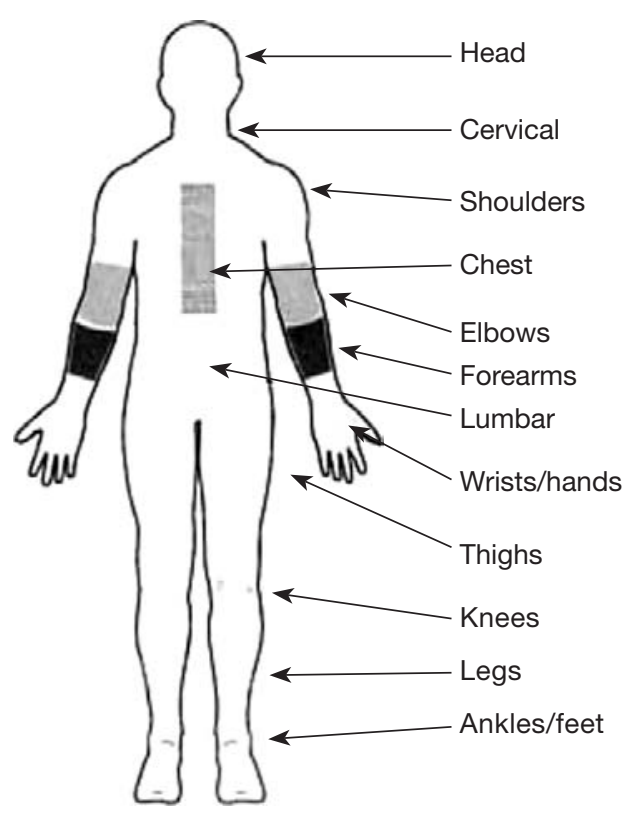

Figure 1. Anatomic regions investigated by the Nordic Musculoskeletal Symptoms Questionnaire ${ }^{1}$ 
descriptive analysis of socio-demographic variables was performed. After checking data normality (Shapiro-Wilk test), quantitative variables were presented by central trend and variability measures (mean and standard deviation). Nominal or categorical variables were presented by frequencies distribution with significance level of $5 \%$.

This project was approved by the Research Ethics Committee, University of Pernambuco - UPE, in compliance with Resolution 196 from October 10, 1996 of the National Health Council (CAAE: 16622513.2.0000.5207).

\section{RESULTS}

Sample was made up of 49 professors of all UPE-Petrolina departments, with predominance of health area courses with a total of $67.3 \%$ of evaluated professors. Gender distribution has shown that among studied professors, $71.4 \%$ were females and 28.6\% were males. Age mean and standard deviation were $39.12 \pm 10.73$, varying between 25 and 63 years. When analyzing for how long professors have been teaching at UPE - Petrolina, mean and standard deviation were $6.54 \pm 7.65$ years with minimum of 0.5 year and maximum of 33 years. Most prevalent weekly workload among professors has varied between 31 and 40 hours $(77.6 \%)$, as shown in figure 2 .

When asked about general professional satisfaction, excluding financial issues, $91.8 \%$ have answered being happy and $8.2 \%$ being not happy. About perception of tiredness level, 12.2\% have reported being tired, $65.3 \%$ a little tired and $22.4 \%$ very tired. Mean and standard deviation for daily hours remaining standing up to carry out teaching activities were $4.53 \pm 1.95$ hours. Through IPAQ answers, it was observed that $44.9 \%$ of evaluated professors are sedentary, as shown in figure 3.

Based on NMSQ results, one may infer that $85.7 \%$ of professors have stated feeling some type of musculoskeletal symptom (pain, discomfort, tingling and numbness), being that from these professors, $64.3 \%(n=42)$ have reported that symptoms are related to and worsen with teaching activities, as shown in figure 4 .

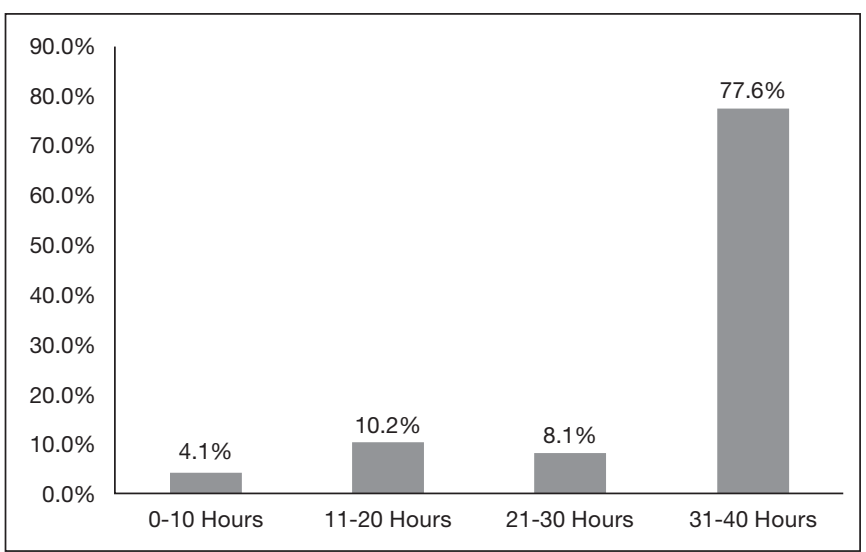

Figure 2. Prevalence of professors with regard to weekly workload at University of Pernambuco - Petrolina Campus $(n=49)$
Figure 5 shows the distribution of symptoms by anatomic region reported by professors in the NMSQ. Lumbar region was the most prevalent and was reported 23 times $(54.8 \%$ ) Musculoskeletal symptoms intensity reported by volunteers and collected by VAS are shown in table 1, being most affected anatomic region with severe intensity the region of upper limbs, with $36.8 \%$ of reports based on total number of professors reporting having some symptom $(n=42)$.

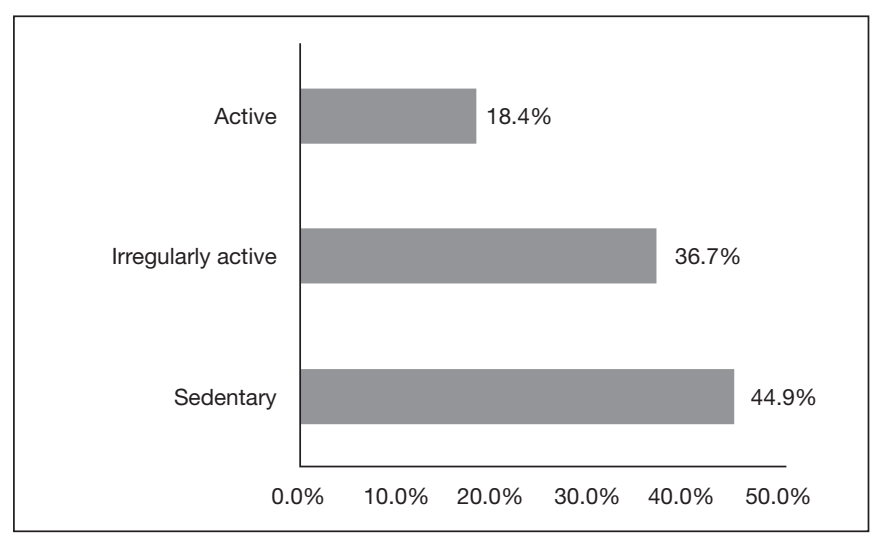

Figure 3. Distribution of professors by level of physical activity $(n=49)$

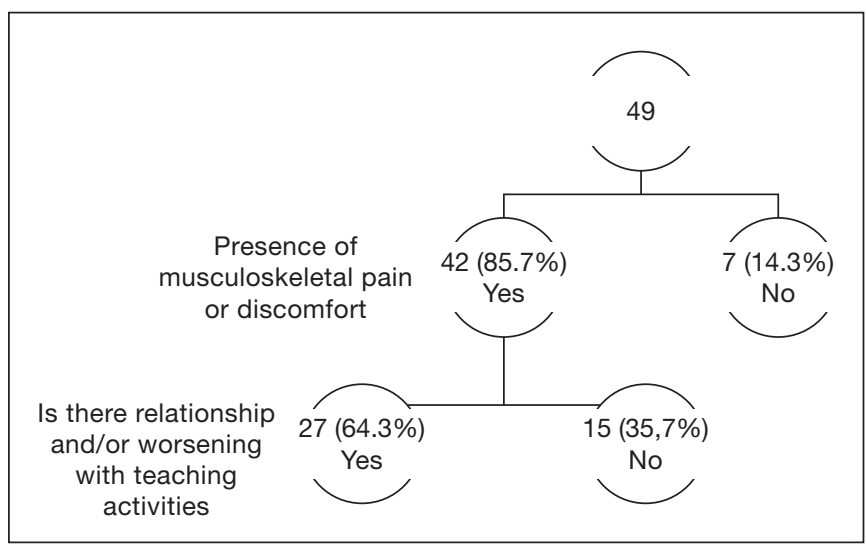

Figure 4. Disposition of professors according to the presence of musculoskeletal symptoms and perception of relationship and worsening with teaching activities $(n=49)$

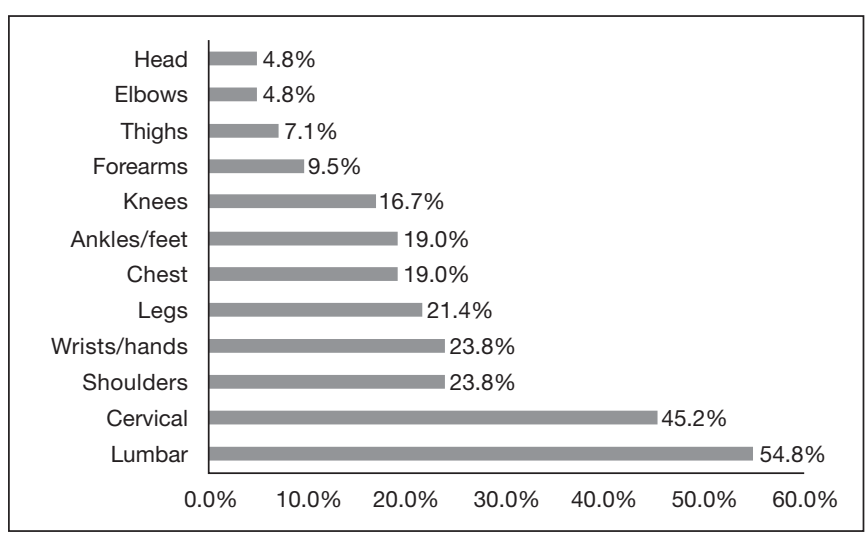

Figure 5. Distribution by frequency of most affected anatomic regions $(n=42)$ 
Table 1. Frequency of musculoskeletal symptoms intensity reported by professors, according to visual analog scale

\begin{tabular}{lccc}
\hline Anatomic regions & Mild & Moderate & Severe \\
\hline Spine $(n=31)$ & $28.1 \%$ & $50.0 \%$ & $21.9 \%$ \\
LLLL $(n=25)$ & $44.0 \%$ & $24.0 \%$ & $32.0 \%$ \\
UULL $(n=19)$ & $42.1 \%$ & $21.1 \%$ & $36.8 \%$ \\
\hline
\end{tabular}

LLLL: lower limbs; UULL: upper limbs.

\section{DISCUSSION}

Results have shown a sample of professors with mean age of 39.12 years and predominance of females $(71.4 \%)$. This scenario may be historically explained by the process of females entering work market, where many have chosen the educational field, being this profession still largely occupied by females ${ }^{15}$.

Mean time teaching at UPE - Petrolina was 6.54 years with most frequent workload (77.6\%) varying between 31 and 40 hours, thus representing a majority with two workloads. In addition, according to article 67 of the Law of National Education Guidelines and Bases ${ }^{16}$, hours dedicated to prepare lessons, correct tests and to study should also be part of total weekly hours. So, one may assume that this number is higher and, as a consequence, when increasing workload the exposure period to different risk factors is also increased ${ }^{17}$.

Professors are among those suffering the most with exposure to workplace risks, since workplace is often conflicting, associated to high professional requirements, which may increase stress load and impair physical and mental wellbeing of workers, bringing consequences to their health and working context ${ }^{18}$. So, professional satisfaction may be affected; however, among participants of this study, all have reported being professionally happy.

From evaluated professors, $87.7 \%$ have reported feeling some level of tiredness and one possible cause for such perception might be sedentariness, which may make individuals more prone to diseases, directly interfering with the level of tiredness and also with working productivity ${ }^{19}$. Results have shown $44.9 \%$ of sedentary professors, confirmed by Fernandes et al. ${ }^{20}$ who carried out a study with basic education professors and have found $80.7 \%$ with inadequate physical activity level. They have also observed, in a multivariate analysis, association between inadequate physical activities and the presence of musculoskeletal symptoms among investigated professors.

There has been high prevalence of musculoskeletal pain and discomfort among UPE - Petrolina professors; $85.7 \%$ of evaluated professors, similarly to other studies with basic education professors ${ }^{20}$ which have shown the presence of symptoms in $93.0 \%$ of all evaluated individuals, and with elementary education professors ${ }^{11}$ with $100 \%$ of professors reporting musculoskeletal pain or discomfort. Such results show that there is no difference on musculoskeletal disorders among professors of different educational levels.
The predominance of musculoskeletal pain and discomfort symptoms in lumbar spine of professors was also found by Carvalho \& Alexandre ${ }^{17}$, who evaluated 2006 elementary school professors and have found a prevalence of $63.1 \%$ of musculoskeletal symptoms in lumbar region. Such study reinforces the prevalence of $54.8 \%$ of lumbar spine disorders presented by our results. Several are the justifications presented in the literature for this high percentage, among them, poor postures adopted during work, performing repetitive activities and lack of fitness ${ }^{21}$.

High pain prevalence in cervical region is also mentioned by studies both with professors and other workers ${ }^{18,21}$, with supposed associations with head tilting movements and especially with muscle tensions generated by the maintenance of postures for long periods of time, causes which are also part of the daily life of evaluated professors.

The high incidence on lower limbs (LLLL) is being point$\mathrm{ed}^{11}$ as being caused by the maintenance of standing up posture for a relatively long time, often necessary to perform their work. Among professors reporting pain, 59.52\% have referred LLLL pain and discomfort and $32.0 \%$ have classified them as severe.

The Ministry of Health points that preventing WRMD should be based on strategies improving workers' health in their workplaces, alerting them about ergonomic and environmental risks, including physiotherapeutic assistance to evaluate, guide and, if necessary, treat possible disorders.

\section{CONCLUSION}

This study has shown that the prevalence of musculoskeletal symptoms among evaluated professors was very high, being that the majority has reported close relationship of such symptoms with teaching activities, being inactive aspects of WRMD.

Studies with larger sample sizes are suggested so that possible correlations and associations may be statistically evidenced, as well as to demonstrate external validity in addition to internal validity. This is needed to supply evidences for a global intervention for college professors, focused on preventing injuries, linked to ergonomic strategies directed to movements, postures and the whole overload required during work, thus decreasing the prevalence of WRMD, improving professors' quality of life and productivity.

\section{REFERENCES}

1. Hugue TD, Pereira Júnior AA. Prevalência de dor osteomuscular entre os funcionários administrativos da Unifebe. Rev Unifebe. 2011;1(9):1-9.

2. Souza AC, Coluci MZ, Alexandre NM. Sintomas osteomusculares em trabalhadores da enfermagem: uma revisão integrativa. Cienc Cuid Saúde. 2009;8(4):683-90.

3. Alcântara MA, Nunes GS, Ferreira BC. Distúrbios osteomusculares relacionados ao trabalho: o perfil dos trabalhadores em benefício previdenciário em Diamantina (MG, Brasil). Cien Saúde Colet. 2011;16(8):3427-36.

4. Barboza MC, Milbrath VM, Bielemann VM, Siqueira HC. Doenças osteomusculares relacionadas ao trabalho (DORT) e sua associação com a enfermagem ocupacional. Rev Gaúcha Enferm. 2008;29(4):633-8.

5. Carlotto SM, Câmara GA. Preditores da síndrome de Burnout em professores. Rev Assoc Bras Psicol Escol Educ. 2007;11(1):101-10.

6. Pinheiro FA, Troccoli BT, Carvalho CV. [Validity of the Nordic Musculoskeletal 
Questionnaire as morbidity measurement tool]. Rev Saude Publica. 2002;36(3):30712.Portuguese.

7. Suda EY, Coelho AT, Bertaci AC, Santos BB. Relação entre nível geral de saúde, dor musculoesquelética e síndrome de Burnout em professores universitários. Fisioter Pesq. 2011;18(3):270-4.

8. WeschenfelderZF, Trindade AG. Trabalho docente e desenvolvimento capitalista: uma articulação perversa para a saúde do educador. Rev Synergismus Scyentifica UTFPR. 2011;4(1):1-7.

9. Araújo TM, Carvalho FM. Condiçóes de trabalho docente e saúde na Bahia: estudos epidemiológicos. Educ Soc. 2009;30(107):427-49.

10. Maciel RH, Albuquerque AM, Melzer AC, Leônidas SR. Quem se beneficia dos programas de ginástica laboral.Cad Psicol Soc Trabalho. 2005; 8(1): 71-86.

11. Mello EM, Caixeta GF, Caixeta A. Prevalência de lesóes osteomusculares em professores do ensino fundamental. Rev Saude CESUC. 2010;1(2):1-13.

12. Servilha EA, Arbach MP. Queixas de saúde em professores universitários e sua relação com fatores de risco presentes na organização do trabalho. Rev Disturb Comum. 2011;23(2):181-91.

13. Huskisson EC. Measurementofpain. Lancet. 1974;304(7889):1127-31.

14. Benedetti TR, Antunes PC, Rodriguez-Añez CR, Mazo GZ, Petroski EL. Reprodutibilidade e validade do Questionário Internacional de Atividade Física (IPAQ) em homens idosos. Rev Bras Med Esporte. 2007;13(1):11-6.
15. Delcor NS, Araújo TM, Reis EJ, Porto LA, Carvalho FM, Oliveira e Silva M, et al. [Labor and health conditions of private school teachers in Vitória da Conquista, Bahia, Brazil]. Cad Saude Publica. 2004;20(1):187-96.Portuguese.

16. Castro MLO. A educaçấo na Constituiçăo de 1988 e a LDB: Lei de diretrizes e bases da educação nacional. Brasília: André Quicé; 1998. 278p.

17. Carvalho AJ, Alexandre NM. Sintomas osteomusculares em professores do ensino fundamental. Rev Bras Fisioter. 2006;10(1):35-41.

18. Caran VC, Freitas FC, Alves LA, Pedrão LJ, Robazzi ML. Riscos ocupacionais psicossociais e sua repercussão na saúde de docentes universitários. Rev Enferm. 2011;2(19):255-61.

19. Salve MG, Theodoro PF. Saúde do trabalhador: a relação entre ergonomia, atividade física e qualidade de vida. Salusvita. 2004;23(1):137-46.

20. Fernandes MH, da Rocha VM, da Costa-Oliveira AG. [Factors associated with teachers' osteomuscular symptom prevalence]. Rev Salud Publica. 2009;11(2):256-67. Portuguese.

21. Mozzini CB, Polese JC, Beltrame MR. Prevalência de sintomas osteomusculares em trabalhadores de uma empresa de embalagens metálicas de Passo Fundo - RS. RBPS. 2008;21(2):92-7.

22. Ministério da Saúde (BR). Diagnóstico, tratamento, reabilitaçăo e fisiopatologia das LER/DORT. Brasília: 2001. Série A. Normas e Manuais Técnicos. 